\title{
Applications of Voice/Sound Sensors in Railroad Field
}

\author{
Ichiro Shibasaki Senior Member (Asahi Kasei Corporation) \\ Makoto Shozakai Non-member (Asahi Kasei Corporation)
}

Keywords : Speech Recognition, Voice/Sound Sensor, Two-Dimensional Visualization, Multidimensional Scaling, Railroad Field

Sensors and informatics have not been fused into one so far. However, rapid progress of electronics and information technologies is bringing a frontier, that is, senso-informatics that is an inter-disiplinary area between sensors and informatics. It is true that automatic speech recognition (ASR) is the most advanced technology field in the senso-informatics.

The ASR is the technology which identifies words contained in the speech signal sensed by the microphone with using informatics composed of two majors components such as signal processing and pattern matching. The purposes of signal processing part are to cancel ambient noises and distortions from speech spectrum and to extract acoustic features. On the other hand, the pattern matching part outputs the most likely words by quick search algorithm named Viterbi decoding by refering to statistical models which are often represented with the HMM (Hidden Markov Model) framework.

As the ASR has been firmly believed to be an important region in the artificial inteligence, the most of works related to the ASR have been focusing on human speech and voices. But, there is no doubt that the ASR technologies are easily applicable to all kinds of sound captured by the microphone.

The ASR market is still on its way to be grown as a popular one because there exists a negligible gap between the expected performance level from the market and the feasible performance one by the-state-of-the-art ASR technologies. It is urgent for the ASR vendors to provide performance guarantee to the market. To establish performance guarantee to real world applications, it is necessary to grasp an acoustic space of microphone input in adverse environments.

To help analysing whole acoustic space, one of the authors' research group proposed multidimensional scaling techniques called COSMOS method and its simplified derivative one called

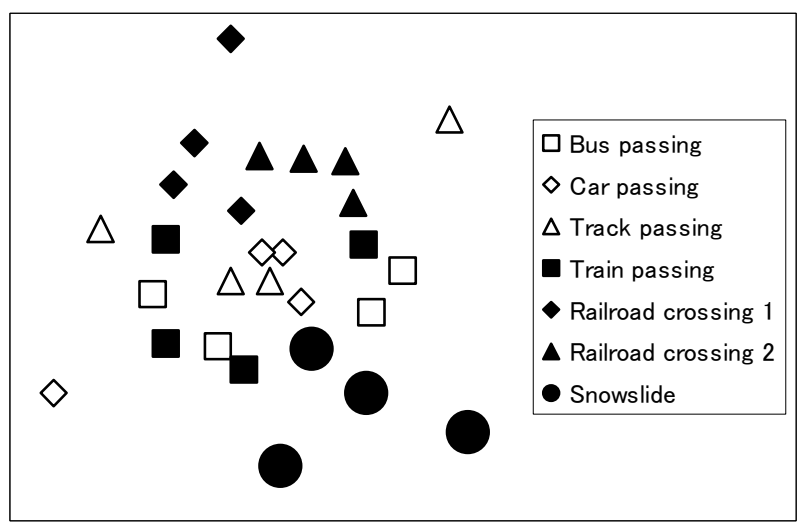

Fig. 1. Two-dimensional map of sounds simplified COSMOS method. By combining conventional multidimensional scaling algorithm which is capable of projecting sets of multidimensional signals onto two-dimensional surface and distance measure between HMMs or multidimensional vector series, the COSMOS method or the simplified COSMOS method provides two-dimensional map of sets of phonemes embedded in human voice. One of the advantages of the COSMOS method and the simplified COSMOS method is to able to present rough sketch of whole acoustic space in visible map called COSMOS map. This visualization supports human capabilities of visual perception and pattern understanding of unvisible original multidimensiona space significantly. The visualization effect gives rise to new ideas of pattern recognition applications to everybody. Fig. 1 shows an example of the COSMOS map, where acoustic parameter series of three sound categories such as automotive field sounds (bus, passenger car and track), railroad field sounds (train and two railroad crossings) and snowslide sound. It is observed that sounds in one category are gathered. Automotive field sounds and railroad field sounds are splitted. Furthermore, snowslide sound is isolated from both automotive field sounds and railroad field sounds. These observations suggest that these three category sounds might be distinguished each other.

By utilizing the ASR technologies and the COSMOS methods, we are ready to propose new applications in railroad field.

(1) Monitoring train motor-man's operation behaviour : The voice sensor of combination of microphone and the ASR system equipped in the motor-man's booth is capable of monitoring his/her operation behaviour. If he/she is drowsy, timing and spectrum of voice uttered with finger action varies from the ones at awake condition.

(2) Monitoring of landslide and snowslide : The conventional approaches to detect landslid and snowslide are stretched wire, inclination sensor and so on. The demerit of these ways is that the detection of landslide is just at direct contact of earth and sand to those sensors. The speed of landslide and snowslide are about 20-40 kilo meters per hour (5.6-11.1 meter per second) and about 100-200 kilo meters per hour (27.8-55.6 meter per second). On the other hand, the sound speed is around 340 meters per second. It means that air vibration (sound) transmits landslide event much faster than conventional sensors. This speed advantage of sound over earth and sand is much more beneficial to escape critical danger. Once the sound sensor of combination of microphone with the ASR system embedded along railroad lines detects some significant sound and the sound is projected and highlighted in the sound COSMOS map displayed in dashboard in front of motor-man, it is helpful for him/her to judge whether it is a notice prior to that the earth and sand covers over railroad line. If it seems so, the motor-man can stop the train to escape tragic acccident. 


\section{鉄道分野における音声・音響センサの応用 \\ 上級会員 柴㟝 一郎* 非会員 庄境＼cjkstart誠** \\ Applications of Voice/Sound Sensors in Railroad Field \\ Ichiro Shibasaki*, Senior Member, Makoto Shozakai**, Non-member \\ This paper presents automatic speech recognition as one of the most advanced examples in the senso-informatics arena and a new method of statistical multidimensional scaling technique which enables projection of multidimensional statistical models onto visible two-dimensional space. Finally, it is discussed that a speech and sound sensors based on both the speech recognition technologies and the statistical multidimensional scaling method are applicable as practical applications in a railroad field.}

論 文

キーワード : 音声認識, 音声・音響センサ, 二次元可視化, 多次元尺度構成法, 鉄道分野

Keywords : Speech Recognition, Voice/Sound Sensor, Two-Dimensional Visualization, Multidimensional Scaling, Railroad Field

\section{1. はじめに}

従来，センサとインフォマティクス（情報科学）は融合 されることはなかった。その理由は，センサ分野とインフ オマティクス分野がそれぞれの領域で閉じた活動を繰り返 してきたからである。近年のエレクトロニクス技術や情報 技術の急速な進展は，これまでの常識を覆し，センサ領域 とインフォマティクス領域の積集合としてのフロンティア 領域を形成しつつある。そこで，ケモインフォマティクス やバイオインフォマティクスなどの過去の命名法に習い, センサとインフォマティクスの融合領域を本論文ではセン ソインフォマティクスと命名することとする。センシング という用語も使われているようであるが, インフォマティ クスの意義を強調する意味で, センソインフォマティクス と呼ぶことにする。実は，その尖兵役を果たしているのが， 音声認識の分野である。音声認識は, マイクロフォンをセ ンサとし，センサから入力される音声の周波数分析や雑音 除去などの信号処理と音声パターンの統計的変動モデルを 用いた照合処理から成るインフォマティクスを用いて，音 声に含まれる言葉を同定する技術である。実はこれまで, 音声認識は人工知能分野の一領域であるヒューマンマシン インタフェースとしての位置付けで研究されることが主で あった。勢い, マイクロフォンの入力は人間の発した音声 を対象とすることがほとんどであった。しかしながら，音

\footnotetext{
* 旭化成 (株) 新事業本部

干416-8501 静岡県富士市鮫島 2-1

Central Research Labs., Asahi Kasei Corporation

2-1, Samejima, Fuji-city, $\bar{\top} 416-8501$

** 旭化成 (株) 新事業本部 情報技術研究所

干243-0216 厚木市岡田 3050 厚木アクストメインタワー $22 \mathrm{~F}$

Information Technology Lab., Asahi Kasei Corporation

Atsugi AXT Main Tower 22F, Okata 3050, Atsugi 243-0021
}

声認識の信号処理や照合処理の技術は，人間の音声に止ま らず，人間の音声を含む音声・音響信号全般に適用可能で ある。

本論文では，第 2 章で，一般的な音声認識技術について 概説し, 人間の音声ばかりでなく, 音響信号全般にも適用 可能であることを述べる。次に，第 3 章で, 音声・音響信 号の空間分析手法として, 筆者の一人の研究グループが開 発した, 統計的多次元空間の二次元可視化手法である統計 的多次元尺度構成法（COSMOS 法）及びその簡略化手法を 紹介する。第 4 章では, 音声・音響信号の二次元可視化の 例を鉄道分野の音響信号を含めて紹介する。最後に，第 5 章では，音声・音響センサの鉄道分野の応用を提案する。

\section{2. 音声認識}

〈2·1〉技 術音声認識の処理は, 信号処理と照 合処理の 2 つのブロックからなる (図 1 参照)。以下では, 最も一般的な処理技術 ${ }^{(1)}$ について概説する。

（1）信号処理 マイクから入力されたアナログの音 声信号は, アナログデジタル変換器 (ADC : Analog-to-Digital Converter) で $8 \mathrm{kHz}, 11.025 \mathrm{kHz}, 16 \mathrm{kHz}$ などのサンプリング 周波数でデジタル化される。そして, 適応フィルター技術 により音源既知の加法性雑音（音響エコー）が除去された 後, $10 \mathrm{~ms}$ などのフレームシフト毎にフーリエ変換により周 波数領域のスペクトルに変換される。このスペクトルから 非音声区間を同定し，その区間の平均スペクトルを雑音ス ペクトルとして動的に推定する。そして, スペクトル減算 法などの手法により信号スペクトルから雑音スペクトルを 減算することにより, 音源未知の加法性雑音が取り除かれ て音声スペクトルが推定される。その後, ケプストラム分 析などの手法により情報量の圧縮が行われ, 音声スペクト 


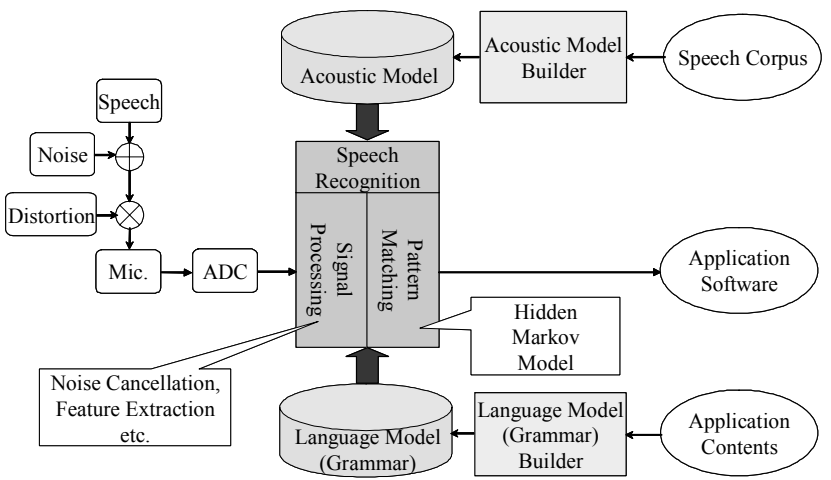

Fig. 1. Block Diagram of Speech Recognition.

ルからケプストラム係数と呼ばれる特徵量が算出される。

（2）照合処理 日本語の音声認識においては, 数百人 から数千人の被験者を無作為に選択し, 日本語音声を収集 する。音素（母音や子音）のラベルと時間情報（始点時刻 と終点時刻）を付与して, コーパスとして整備してファイ ルサーバに蓄積する。このコーパスから隠れマルコフモデ ル（HMM : Hidden Markov Model） 技術 ${ }^{(1)}$ により音素の統計 モデルを学習する。HMM は, 状態遷移が外部から不観測な マルコフモデルとして定式化され，正規分布の線形和によ り観測信号の確率分布をモデル化する。HMMによる統計モ デルの学習方法は数学的に整然と定式化され, HTK (HMM Tool Kit) ${ }^{(2)}$ というソフトウェアツールも公開され, 音声認識 研究の普及に大いに役立った。研究の裾野が広がり, 多数 の音声認識研究者の育成に貢献した。

音声認識の問題は, 観測された信号系列（特徵量系列） を生成する確率が最大となる状態遷移を推定する問題に帰 着される。この問題は, 発声器官の筋肉の動きが形成する 声道の形状の時間変化を推定する問題と同一である。声道 の形状は, 音声に含まれる各音素に対応している。従って, 音声認識の問題は，音素の時系列を推定する問題と等価に なり，単語や文章を認識するプロセスであると定義するこ とができる。長年の研究により, HMM が音声の統計的な時 間遷移と特徵量の話者間のばらつきを両立しながら効率良 く表現できることが多言語での実験で確認されており，現 在では, HMM を用いた最尤推定基準に基づく音響モデル作 成処理とビタビデコーディングと呼ばれる高速照合処理が 音声認識の定番となっている。

近年, 音声認識の実用化技術が加速したのは, 必ずしも 音声に関する科学が進歩したからだけではない。音声科学 はこの 10 年大きな進歩を成し遂げたとは必ずしも言えな い。むしろ，ノイズキャンセルやケプストラム分析などの 信号処理や HMM に代表される統計的モデリングから成る 情報科学あるいは統計科学を音声認識に適用しようとして 工夫を積み重ねてきたからであると言える。多数話者の音 声を収集し，コーパス化が進んだおかげで，HMM を用いて 音声コーパスを統計的に解析することが可能になった。そ れにより, クラスタリング（分類）の技術の知見が蓄積さ
れ，音響モデルの表現精度が飛躍的に高まった。それらの 積み重礼により, ようやく, 雑音や歪みの存在する実環境 でも使える高い精度を発揮する音声認識製品の商品化が可 能なレベルまで到達した。その苦難の歴史の中で, コンピ ユータ, 情報技術, 情報科学が救いの手を差し伸心゙, 音声 認識に果たした役割は計り知れない。半導体技術, マイク ロプロセッサアーキテクチャ技術, ハードディスク技術, コンピュータ技術などの急速な進歩により, 計算コストや 蓄積コストの低価格化の恩恵に浴する環境が整備された。 また, 音声認識の業界では, コーパス整備の重要性が以前 から認識され, 日米欧で各国語の音声コーパス整備を推進 する国家プロジェクトが進められ，広く公開されている。

こうしたコーパスの整備は, 統計的手法によるパターン認 識の適用を促した。

これらが相まって, 音声認識は最先端のセンソインフォ マティクスに成長した。音声認識の教訓に学べば, センサ ソインフォマティクスの適用が成功する条件は, 以下の 3 つである。

条件 1 (出力の因果性)：時間変動を伴うセンサ出力があ る因果関係に従って生成されること。

条件 2(出力の確率的変動性) : センサ出力が観測不能の 摇らぎや雑音などの影響で確率的に変動すること。（観測 不能の摇らぎや雑音などがなく, センサ出力が変動しない 場合は, インフォマティクスは不要である。)

条件 3 (コーパスコストの安価性) : センサ出力信号の取 得コストが安価で, 大量のデータの取得が可能であること。 過去に取得したデータを蓄積した大規模コーパスが存在す るか, 外部から安価にコーパスを購入可能か, 外部に安価 にコーパス収集を依頼可能であること。

これらの条件が満たされるのであれば, 音声認識の技術, 知見はそのまま音響信号全般の認識に適用可能である。

$\langle 2 \cdot 2\rangle$ 応用 音声認識の応用を簡単にまとめる と, 以下の通りである。

（1） ハンズフリー機器操作 自動車の IT 化（ITS： Intelligent Transport System）が進行している。その流れの中 で，例えば，ハンズビジーな（手が塞がった）状況にある 自動車運転中にハンズフリーで携帯電話の受発信操作を行 うための新しいモダリティとして音声が脚光を浴びてい る。また, 自動車運転中にカーナビゲーションの操作を音 声で行うことや, 走行場所の近隣の情報検索に音声を用い る使い方も実用レベルに達しつつある。日本で最も音声認 識の需要が高まっているのは, 自動車の領域である。また, ハンズビジーな医療手術現場で, 患者のカルテを音声で検 索して参照する使い方も実用化されている。物流の分野で は業務作業中のハンズビジーな状態での情報検索・情報入 力の用途で音声認識の潜在的需要は高まっている。

（2）オペレータ代替・モニタリング＼cjkstart米国で最も音声 認識が活用されているのは大規模コールセンター（ヘルプ デスク）のオペレータの代替としての用途である。これに よる人件費の削減メリットは大きいと言われている。また, 
コールセンターでは多くのオペレータが顧客からの問い合 わせ電話に対応しているが，言葉遣いが適切であるか，言 うべき言葉を言っているかを音声認識でモニタリングする ことにより，オペレータのスキルの評価をするというデマ ンドも近年顕在化している。

（3）ディクテーション 文筆業などの職業の人が重 宝して使っているのは, 音声認識技術を用いたディクテー ション（口述）ソフトである。文筆業のように正しい日本 語の文章を書くことに慣れたユーザにとっては，非常に便 利な PC ソフトウェアが出回っている。この応用は, 音声認 識応用の中で最も初期に実用化が進んだが，不特定話者に 対する認識性能が十分でないことや文章を日常的に声で入 力する必要のある人は多くないこと, 文法的かつ意味的に 正しい文章を作成できるユーザの割合はそれほど多くない ことなどから，今では限定的な使用に留まっている。

(4) アノテーション TV 番組や講演などのアーカイ ブ (ライブラリ) を整備する際に, 後で検索し易いように タグ (インデックス) 情報を付与するために, 音声認識を 用いる新しい応用を目指した研究も始まっている。

（5）翻訳・通訳外国人との会話を円滑にするため に，日本語と外国語の間の翻訳・通訳の研究も長年続けら れてきた。限定的な範囲であれば，日本語を音声認識し， 英語や中国語に翻訳した後, 音声合成で外国人に伝えるサ ービスが数年の後に開始される動きもある。

（6）その他音声認識を用いた TV ゲームソフトでの 音声認識の利用も徐々に定着しつつある。

\section{3. 統計的多次元尺度構成法}

〈3・1〉研究の背景音声認識技術の実用化が停滞し た根本原因の 1 つは, 市場が期待する音声認識性能と音声 認識ベンダーが提供する音声認識ソフトウェア製品の性能 との埋めがたい乘離にある。一般に, 前者の方が後者の方 より大幅に高い。場合によっては，前者は体感 $100 \%$ である ことが求められる。それに対して, 実環境における後者の 大幅な性能劣化が市場を落胆させることがしばしば起こつ ている。音声認識性能に関する評価（以下，ベンチマーク と呼ぶ）フローの一般的な手法は, 以下の通りである。ま ず，指定された認識タスクに固有の語彙に対する記述（以 下，認識タスク記述と呼ぶ）に基づいて作成された語彙リ ストを, あるコストの範囲で, 限定的な被験者に発声して 貪い, 音声サンプル（以下, 認識タスク依存評価音声サン プルと呼ぶ）を収集する。次に, 認識タスク依存評価音声 サンプルを用いて, 所定の音声認識システムの認識率を評 価して, 平均值, 最高值, 最低值などを算出する。

従来のこの手法における問題点として, 以下のことが挙 げられる。（1）認識タスクが変わる度に, 限定的な被験者 に依頼して, 認識タスク依存評価音声サンプルを収集する ために，金銭的及び時間的コストが嵩む。（2）被験者の網 羅的な選択に関して確立された方法論に乏しく，限定的な 被験者の選択の正当性の根拠が希薄である。（３）被験者の
不可避な交代が起こった場合，評価基準が経時的に摇らぐ。 （4）音声認識ベンダー毎に独自に認識タスク依存評価音声 サンプルを用意するため, 業界標準が不在である。

市場は, 認識タスク記述を与えただけで, 実環境での認 識性能分布を見積もり, 速やかに提供するよう, 音声認識 ベンダーに求めている。しかしながら, 世界のいずれの音 声認識ベンダーも, 自動車内, 屋内, 屋外などの多様な実 環境における認識性能分布を客観的に評価する技術を確立 できておらず，客観的評価手法に基づく認識性能分布情報 を市場に提供できていない。今こそ, 効率的なベンチマー ク方法論の確立が必要な所以である。認識性能保証ができ ることは, 音声認識アプリケーションの認識タスク記述に 対して, 認識性能分布が予め予測できるベンチマーク技術 を有することを意味する。そのためには，実環境における 様々な日本語音声のバリエーションを把握することが出発 点となる。そのためには, そのバリエーションを網羅する 音声空間全体を把握する手法が必要である。

音声信号は元々 1 次元信号であるが, 多様な周波数情報が 畳夕込まれた特性を有するために, 特徵量は数十次元にも 及ぶ。このくらいの大きさの次元になると, 人間の脳では 直感的な解釈が不可能であり, 数值演算に頼る解析の積み 重ねが欠かせない。それ故, 扱える人口が限定され, 音声 空間の俯瞰的な分析は困難を極めた。そこで，筆者の一人 の研究グループは音声認識の対象である音声空間を 2 次元 の可視空間に写像し, HMMによる音響モデルの開発プロセ スを支援する技術として, 統計的多次元尺度構成法 $(\operatorname{COSMOS} \text { 法 })^{(3)}$ を提案した。この方法は, 音声認識の信号処 理で求められた多次元特徵量から作成される HMM モデル を部分音声空間の近似表現と見なし, HMM モデルの統計的 距離を定義して, 多次元空間上での HMM モデルの相互距 離の総和と写像先の 2 次元の可視空間上での相互距離の総 和の差分が最小になるように最急降下法を用いて非線形写 像を行う。これは, 従来提案されていた多次元尺度構成法 を統計的に拡張した概念と位置付けることができるため, 統計的多次元尺度構成法と呼ぶ。

〈3·2〉Sammon 法 最初に, ベクトル情報を入力と する多次元尺度構成法の古典的手法として提案された Sammon 法(4)を紹介する。

$L$ 次元空間内の $N$ 個のベクトルデータを $P(i)(i=1, \cdots, N)$ で表す。 $P(i)$ に一対一に対応する 2 次元ベクトルを $Z(i)=\left[x_{1}(i) x_{2}(i)\right]^{T}(i=1, \cdots, N)$ と表す。 $x_{q}(i)(q=1,2)$ の初期 值は乱数を与える。 $L$ 次元空間内での $P(i)$ と $P(j)$ の相互距 離を $D(i, j)$ で表す。 $L$ 次元から 2 次元への非線形写像後の 2 次元座標を $Z_{m}(i)=\left[x_{m, 1}(i) x_{m, 2}(i)\right]^{T}(i=1, \cdots, N)$ で表す。 $m$ は, 非線形写像の $m$ 回目の繰り返し時を表す。また, $Z_{m}(i)$ と $Z_{m}(j)$ のユークリッド距離を $\tilde{D}_{m}(i, j)$ で表す。

非線形写像の $m$ 回目の繰り返しにおけるべクトルデータ $P(i)$ の局所的写像誤差 $E_{m}(i)$ を相互距離 $D(i, j)$ とユークリ ッド距離 $\tilde{D}_{m}(i, j)$ の正規化ユークリッド距離の総和で表す とすると， $E_{m}(i)$ は(1)式と(2)式で表される。 


$$
\begin{aligned}
& E_{m}(i) \equiv \frac{1}{c} \sum_{\substack{j=1 \\
j \neq i}}^{N}\left[\left\{D(i, j)-\tilde{D}_{m}(i, j)\right\}^{2} / D(i, j)\right] . \\
& c \equiv \sum_{i=1}^{N} \sum_{\substack{j=1 \\
j \neq i}}^{N} D(i, j)
\end{aligned}
$$

非線形写像により最小化される大局的写像誤差值 $E_{m}$ を 局所的写像誤差值 $E_{m}(i)$ の総和で表すとすると， $E_{m}$ は(3) 式で与えられる。

$$
E_{m} \equiv \sum_{i=1}^{N} E_{m}(i)
$$

非線形写像の $m+1$ 番目の繰り返しにおける座標 $Z_{m+1}(i)$ と $Z_{m+1}(j)$ は, 最急降下法により, (4)式と $(5)$ 式で算出され る。

$$
\begin{aligned}
& x_{m+1, q}(i)=x_{m, q}(i)-\alpha \cdot \Delta x_{m, q}(i) \\
& \Delta x_{m, q}(i)=\frac{\partial E_{m}}{\partial x_{m, q}(i)} /\left|\frac{\partial^{2} E_{m}}{\partial x_{m, q}(i)^{2}}\right|
\end{aligned}
$$

これにより，元の $L$ 次元空間内で近く（遠く）に位置す るべクトルは，2 次元空間内でも相対的に近く（遠く）に写 像される。最小の $E_{m}$ を与える繰り返しの $N$ 個の全ての座標 $Z_{m}(i)$ を記録し，この座標を用いて地図を作成する。

〈3.3〉 COSMOS 法 次に, Sammon 法の入力信号を ベクトルから統計モデルに拡張した, 統計的多次元尺度構 成法 $\left(\operatorname{COSMOS}\right.$ 法) ${ }^{(3)}$ に関して概説する。

一般に, 音声認識システムの音響モデルセットは, 音素 (monophone)，二つ組音素(biphone)，三つ組音素(triphone)に 対応する音声単位モデル毎の HMM の集合体である。従っ て，音響モデルセット $i$ と音響モデルセット $j$ の相互距離 $D(i, j)$ は， (6)式で定義される。

$$
D(i, j)=\sum_{k=1}^{K} d(i, j, k) \cdot w(k) / \sum_{k=1}^{K} w(k)
$$

ここで, $d(i, j, k)$ は，音響モデルセット $i$ のの音声単位 モデル $k$ の HMM と音響モデルセット $j$ の中の音声単位モ デル $k$ の HMM の相互距離を表す。 $w(k)$ は，音声単位 $k$ の HMM の重み（例えば，出現頻度）を表す。 $K$ は，音響モ デルセットにおける音声単位モデルの総数を表す。

音響モデルセット $i$ と音響モデルセット $j$ の全ての音声 単位モデルが同じトポロジーを有する HMM でモデル化さ れ, 状態対応が一対一であると仮定すると, $d(i, j, k)$ は， ( 7 ) ( 9 )式で表される。

$$
\begin{array}{r}
d(i, j, k) \equiv \frac{1}{S(k)} \sum_{s=0}^{S(k)-1} \frac{1}{L} \sum_{l=0}^{L-1} \frac{d d(i, j, k, s, l)}{p p(i, j, k, s, l)} \ldots \ldots \ldots \ldots \ldots . . . . . . . \\
d d(i, j, k, s, l) \equiv \sum_{m_{i}=0}^{M_{i}} \sum_{m_{j}=0}^{M_{j}} p\left(i, k, s, l, m_{i}\right) \cdot p\left(j, k, s, l, m_{j}\right) . \\
c\left(i, j, k, s, l, m_{i}, m_{j}\right) \ldots \ldots \ldots \ldots . . .
\end{array}
$$

$$
p p(i, j, k, s, l) \equiv \sum_{m_{i}=0}^{M_{i}} \sum_{m_{j}=0}^{M_{j}} p\left(i, k, s, l, m_{i}\right) \cdot p\left(j, k, s, l, m_{j}\right)
$$

ここで, $p(i, k, s, l, m)$ は, 音響モデルセット $i$ の音声単位 モデル $k$ の状態 $s$ の次元 $l$ の $m$ 番目の正規分布の重みを表 す。 $S(k)$ は音声単位モデル $k$ の状態数を表す。 $M_{i}$ は, 音声 単位モデル $i$ 正規分布の混合数を表す。また, $c\left(i, j, k, s, l, m_{i}, m_{j}\right)$ は, 音響モデルセット $i$ の音声単位モデル $k$ の状態 $s$ の次元 $l$ の $m_{i}$ 番目の正規分布と音響モデルセッ ト $j$ の音声単位モデル $k$ の状態 $s$ の次元 $l$ の $m_{j}$ 番目の正規 分布間のバタチャリア距離を表す。

(4)式の值 $\alpha$ は, 非線形写像の収束速度を制御するパラメ ータであり, Sammon 法(4)では推奨值として 0.3-0.4 が示唆さ れているが, COSMOS 法においては，0.1 以下の值が適当で あることが分かった。

(4)式によって算出された $\mathrm{x}$ 座標, $\mathrm{y}$ 座標を用いれば，二 次元地図を作成できる。こうして得られる地図を COSMOS 地図と呼ぶ。COSMOS 地図は, HMM が近似的に表現する 統計空間の群れからなる汎関数空間の 2 次元写像と解釈で きる。COSMOS 地図において, $\mathrm{x}$ 軸, $\mathrm{y}$ 軸は特定の物理的意 味を有しない。

〈3.4〉 簡略化 COSMOS 法 COSMOS 法の入力信号 は HMM なる統計モデルであるが, HMM の作成には一般に 50〜100 個程度の学習用サンプルが必要である。この多量の 学習サンプルの収集を行う前に, 数サンプル程度で COSMOS 地図と同様の二次元可視化が行えると便利であ る。そこで, COSMOS 法の入力信号を統計モデルからべク トル時系列に簡略化させた手法について説明する。

ベクトル時系列間の距離を求める手法として, 以前から 動的計画法 DP (Dynamic Programming) を用いた時間正規化 DTW (Dynamic Time Warping) 法 ${ }^{(5)}$ がしばしば利用されてい る。ベクトル時系列 $i$ とベクトル時系列 $j$ に対し, DTW を 施して得られる距離をベクトル時系列 $i$ とベクトル時系列 $j$ の相互距離 $D(i, j)$ と定義し, Sammon 法を適用することに より, COSMOS 地図と同様の二次元可視化が可能である。 この手法を簡略化 COSMOS 法と呼ぶ。簡略化 COSMOS 法 で得られた地図は, COSMOS 法で得られた地図に比べて統 計的な信頼度は低いが, 生のベクトル時系列を用いるため 異なる種別の音響信号間の遠近関係を俯瞰するのには簡便 な方法と言える。

\section{4. 音声・音響信号の二次元可視化地図}

〈4·1〉 音声信号のみの場合 数十人の日本人毎に音 声から特定話者音素 HMM を作成する。各特定話者の音素 $\mathrm{HMM}$ の中から子音 HMM のみを選抜し, それらに COSMOS 法を適用して得られた COSMOS 地図の例を示す（図 2 参 照)。ここで, 各子音毎に複数の同一色の点が表示されてい るのは, 数十人のそれぞれの特定話者子音 $\mathrm{HMM}$ が表示さ れているためである。1)各子音毎に点が集合していること， 


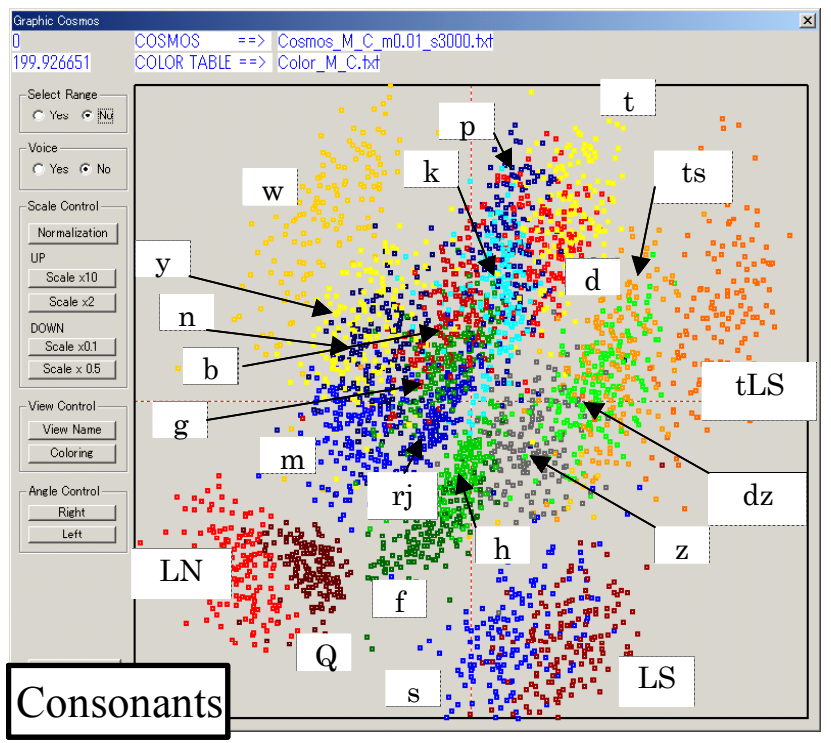

Fig. 2. Two-Dimensional Map of Japanese Consonants.

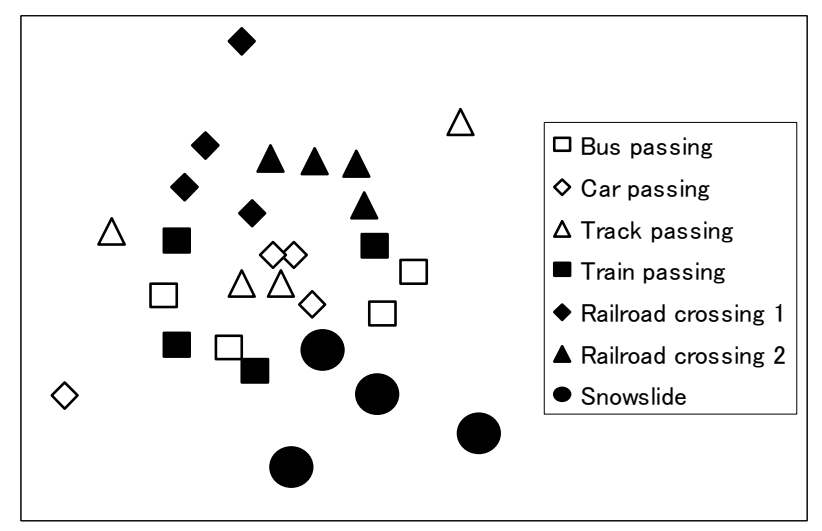

Fig. 3. Two-Dimensional Map of Sounds.

2)類似した子音はお互いに近接していること，3)子音間でオ 一バーラップがあることが観察できる。オーバーラップが 多い子音は，相互に酷似しており識別が困難であるとのこ れまでの評価結果と合致する。

〈4·2〉 音響信号へ適用した場合＼cjkstart次に，音声信号ば かりでなく，音響信号へ適用した場合の二次元可視化の例 を示す。市販されている効果音の $\mathrm{CD}^{(6) \sim(8)}$ から, 自動車関連 音（バスの通過音，乗用車の通過音，トラックの通過音）, 鉄道関連音（電車の通過音， 2 種類の踏み切り音）及び雪崩 音の計 7 種の音響信号を選抜し, 最も典型的な区間から 1 秒の波形を連続して 4 個抽出した後, 簡略化 COSMOS 法を 用いて COSMOS 地図を作成した（図 3 参照）。多少の混合 はあるが，自動車関連音と鉄道関連音が分離して位置して いることから，自動車関連音と鉄道関連音の識別は比較的 容易であることが示唆される。また, 自動車関連音, 鉄道 関連音と雪崩音の分離も十分可能であることが見て取れ る。
図 3 は，自動車関係音，鉄道関係音と雪崩音のそれぞれ について，4 サンプルの音響信号から簡略化 COSMOS 法を 用いて COSMOS 地図を作成したが，これらの信号のサンプ ル数が十分に確保できる場合は, それぞれの HMM を作成 して, COSMOS 法を適用することも可能である。

高次元情報で表現される音響空間上に存在する情報を, 人間の目で可観測な 2 次元平面に近似的に表示することで, 人間の視覚パターン認識能力による音響空間の直感的把握 を支援することができる。また，既に作成済みの音響空間 COSMOS 地図の上に, 新たな音響情報を重畳表示できれば, 音響空間全体における位置取りを把握しやすい。

\section{5. 鉄道分野における音声 - 音響センサの応用}

〈5·1〉運転士の運転業務のモニタリング＼cjkstart電車の運 転士の業務においては, 発話行動を伴う指差呼称動作が一 般化している。音声認識機能を備えた音声センサを電車の 運転席に設置し, 運転士の指差呼称音声を常時モニタリン グすることにより, 運転士の勤務態度をモニタリングする ことができる。運転士に眠気が生じた場合の指差呼称音声 は, 完全覚醒時のそれと比較して, 発声タイミングやスペ クトル形状が変化する。この変化を測定することにより， 眠気度合いを計測することができる。眠気度合いが強い場 合は警告音を発するなどして運転士を覚醒させるという応 用が考えられる。

〈5·2〉 土砂崩れ, 土石流, 雪崩のモニタリング 従 来, 山間部の土砂崩れ, 土石流, 雪崩のセンサとして, ワ イヤが敷設され, ワイヤが物理的に切断された場合に警報 を発するシステム ${ }^{(9)}$ が実用化されている。また, 鉄道の線路 近傍に傾斜センサを設置し, 土砂崩れなどで地面の傾斜が 変化した場合に接近する電車の運転手に警報を発するとい うシステム ${ }^{(10)}$ も開発されている。しかし，これらの方式で は土砂や雪がワイヤ, 傾斜センサに直接到達しなければ検

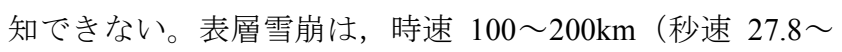
$55.6 \mathrm{~m})$ と新幹線並夕の速度であると言われる。また, 全層 雪崩でも, 時速 40〜80km（秒速 11.1〜22.2m） と自動車並 みの速度である。土砂崩れは時速 20〜 40km（秒速 5.6〜 $11.1 \mathrm{~m})$ の速度である。一方, 音速は温度によっても変わる が秒速 $340 \mathrm{~m}$ 前後である。従って, 音は雪崩の 6.1 倍以上, 土砂崩れの 30.6 倍以上の速度を有する。この速度差を利用 すれば，より早く土砂崩れなどの危険発生を捕捉できると 考えられる。線路付近の土砂崩れなどの危険箇所に防水・ 防風対策を施したマイクロフォンと音響認識装置を接続し た音響センサを設置し，常時，音響信号をモニタリングす ることにより, 雪崩や土砂崩れなどの自然災害を早期に検 知することが可能になる。さらに, 地震計などの振動セン サとの組み合わせにより, より精度の高い自然災害の早期 検知が可能になる。

音響認識装置で音響信号の種別を識別する自動方式もい ずれ可能となると思われる。また, 半自動方式として, マ イクロフォンで取得した音響信号に対する尤度が大きい音 
響 $\mathrm{HMM}$ を 1 つ以上探索し，その音響 $\mathrm{HMM}$ を音響空間 COSMOS 地図の上でハイライト表示して運転士に提示する ことも可能である。運転士は，音響空間 COSMOS 地図上の ハイライト表示を視認し，ハイライトパターンを判断する ことにより, 雪崩や土砂崩れなどの危険を予知して, 電車 に制動をかけるという運転行動を早めに取ることにより， 崩落土砂への衝突などの事故を回避することができる。

〈5·3〉 全ての音響信号のモニタリング＼cjkstart電車の走行 環境においては，その他の様々な音響信号が自然発生して いる。例えば，踏切に複数のマイクロフォンを設置し，踏 切を渡る自動車の走行音をモニタリングすることにより， 踏切内に自動車が止まっていないかを判断することができ る。また，電車自身に複数の音響センサを設置しておくこ とにより, 線路上の置石や電車への投石などの事象を分析 することも可能であろう。電車, 線路, 踏切に音声センサ, 音響センサを搭載し，これらが日常的に出力し続ける音響 信号をメモリカードなどの一次記憶媒体に記録し，通信手 段を介してハードディクスなどの二次記憶装置（サーバ） に蓄積する仕組みを具備することができれば，音響信号の コーパス化が実現される。もし, 第 2 章の条件 $1 \sim 3$ が満た されるのであれば，本論文で紹介した技術は例外なく適用 できる。

\section{6. おわりに}

本論文では，センソインフォマティクスの尖兵役である 音声認識を事例として, センソインフォマティクスの基本 技術や成立要件について論じた。また, センソインフォマ ティクスが鉄道の分野にも例外なく適用可能であることを 述べた。従来, センサ分野とインフォマティクス分野は, 音声認識を例外として, 研究者・技術者が互いに交流する ことはほとんどなかった。インフォマティクスのコストが 大幅に削減された今こそ, 鉄道分野における音声・音響セ ンサの新たな応用を開拓するために, 鉄道分野, センサ分 野とインフォマティクス分野のコミュニティの研究者・技 術者の交流を促進する社会的仕組みを整備することが必要 ではないだろうか。

(平成 19 年 4 月 11 日受付, 平成 19 年 7 月 24 日再受付)

\section{文献}

（1）鹿野清宏・中村 哲・伊勢史郎:「音声・音情報のディジタル信号処 理」, 昭晃堂 (1997)

(2) http://htk.eng.cam.ac.uk/

(3) 庄境 誠: 「複数音声コーパスの俯瞰的分析」, 情報処理学会, 第 7 回音声言語シンポジウム, No.SLP59-23 (2005)

(4) J. W. Sammon : "A nonlinear mapping for data structure analysis", IEEE Trans. Computers, Vol.C-18, No.5, pp.401-409 (1969-5)

(5) 古井貞熙 : 「ディジタル音声処理」, 東海大学出版会 (1985)

（6） CD：「効果音大全集」, ビクターエンターテインメント（株）(2005)

（7） CD :「B.G.M.効果音」, ビクターエンターテインメント (株) (2005)

（8） CD：「効果音ベスト」，キングレコード（株）(2004)

(9) http://www.sec-keisoku.com/case/wire.html

(10) http://japan.cnet.com/news/ent/story/0,2000056022,20145147,00.htm

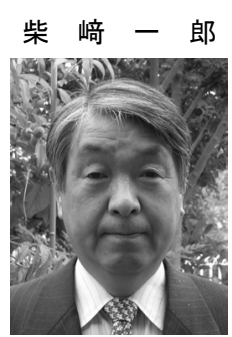

（上級会員） 1942 年 11 月 17 日生。1971 年 3 月東京教育大学大学院理学研究科物理学専攻 博士課程修了 (理学博士)。物理教室勤務を経 て 1974 年 1 月旭化成工業（株）（現 旭化成 (株) ) 入社, 薄膜のホール素子開発を手がける。 技術研究所室長, チーフリサーチフェロー等を 経て 2003 年 10 月, 旭化成グループフェロー, 2004 年 10 月より, 柴㠃研究室長, 2006 年旭化 成新事業本部 顧問, 2004 年 4 月より東京工業大学大学院生命理工 学研究科 COE 特任教授を兼任。1988 年 3 月には開発した「高感度 InSb ホール素子と量産化」で大河内記念生産賞（社名表彰）受賞, 1998 年春には科学技術庁長官賞受賞, 2003 年春, 「高感度 InSb ホ ール素子技術の開発」の業績で紫綬褒章受章。専門は InSb など狭ギ ヤップ化合物半導体薄膜の研究と磁気センサ応用。

庄境誠（非会員） 1958 年 5 月 13 日生。1983 年 3 月京

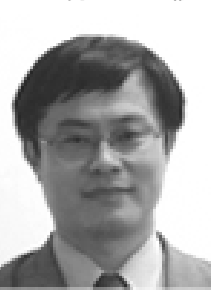
都大学大学院工学研究科数理工学専攻前期博 士課程修了。1983 年 4 月旭化成工業 (株) 入社。 1998 年 3 月奈良先端科学技術大学院大学情報 科学研究科音情報処理学専攻後期博士課程修 了。工博。現在旭化成（株）において, 新事業 本部音声ソリューションビジネス推進部部長,

新事業本部情報技術研究所所長。旭化成グルー プフェロー。1985 年から音声認識の研究開発に従事。2001 年から 統計的多次元尺度構成法 (COSMOS 法) の研究に従事。2006 年 3 月に COSMOS 法に関する研究業績に対し, 情報処理学会山下記念 研究賞を受賞。専門は音声認識を中心とする音声情報処理, パター ン認識処理及びデジタル信号処理。 